\title{
Paradigms of Hadith Science Study Program: The Comparison between UIN Sunan Kalijaga Yogyakarta and Kolej Universiti Islam Antarabangsa Selangor (KUIS) Malaysia
}

\author{
Wahidul Anam \\ IAIN Kediri \\ \{wahidulanam@yahoo.co.id\}
}

\begin{abstract}
Each Hadith Science study program has its own learning paradigm which can be seen from the curriculum structure of the study program. This paradigm model of Hadith studies program in University was interesting study to form learning hadith paradigm map. This research used qualitative approach with direct observation and interview methodology taken from Kolej Universiti Islam Antarabangsa Selangor (KUIS), Malaysia, and UIN Sunan Kalijaga Yogyakarta. The study revealed that Hadith Science study program at KUIS Malaysia tended to apply the normativity paradigm as shown in the structure of study program's curriculum. On the other hand, the hadith science study program at UIN Sunan Kalijaga Yogyakarta tended to use historicity paradigm model. In addition, UIN Sunan Kalijaga Yogyakarta also a combination of normativity and historicity approaches in some subjects (integrative method).
\end{abstract}

\section{Introduction}

The attention of Muslims to hadith studies has been far behind compared to the study of Al-Qur'an and other sciences. In Indonesia, Islamic studies have focused more on fiqh and sufism than on hadith. Hadith studies have only been discussed at a basic level, without further analysis of the sanad (chain of narration)and matn (text) of hadith. The limitations of hadith studies in Indonesia can be seen in the methods and results of legal stipulations used by Islamic organizations and institutions in issuing fatwa (religious verdicts).

Books of fiqh, tafsir (Qur'anic interpretation), and sufism using Malay language have been widely circulated in Indonesia from 17 century AD. For example, Abdul Ra'uf al-Sinkili (d. $1693 \mathrm{M})$ wrote a fiqh book Mir'ât al-Tullâb in 17th century AD; Syekh Jalaluddin wrote Hidâyah 'Awwâm in 1719; by, 3) Muhammad Arsyad al-Banjari (d. 1812M) wrote Sabîl alMuhtadîn in 1778; Abd al-Rauf al-Sinkili wrote Kifâyah al-Muhtâjîn (book on sufism) in 17th century and Tarjuman al-Mustafîd (tafsir book) in the 17th century (Wahid, 2006). These books are examples of Indonesian scholars' works which do not represent any science of hadith.

Tasrif (2007) suggested thathadith studies in 1970s still had used a limited literature similar to the one used in Islamic boarding schools and madrasa. This condition shows that the hadith studies at the tertiary level in Indonesia is still lagging behind. Initially, the hadith 
studies at Islamic Religious Higher Education (PTKI) have only put as a secondary study and not yet taught independently. Hadith studies had been taught under sharia faculty and had not become a separate study program. In 1990, however, hadith studies were moved to the Faculty of Ushuludin under the name of the department of hadith interpretation (Tafsir Hadits). In 1990s, the study of hadith still received little but growing attention, although in general the department of hadith interpretation focused more on advances in the science of the Qur'an and tafsir. Eventually the department of hadith studies, which specifically studied the field of hadith, emerged in 2013.

The department of Hadith studies was still relatively new after separated from the the Department of Hadith Interpretation. However, the scientific paradigm in the department is still relatively underdeveloped in contrast to the more advanced study of Al-Qur'an. The current research emphasized on the paradigm of hadith studies in PTKI and factors which influence the paradigm of hadith studies in PTKI. This study focused on comparing a domestic university (UIN Sunan Kalijaga Yogyakarta) and an international Islamic one (Islamic Antarabangsa Universiti Selangor, Malaysia).

\section{Research Methodology}

This study used a qualitative approach which aimed to describe the integrity of a problem by understanding the meaning of problems. This qualitative approach focused on general principles which are based on the manifestation of symptom units that existed in human life. This method was also called an artistic method because the research process was more artistic and an interpretive method because the results of the study were collected from the field data interpretation (Hayati, 2015).

The researchers gathered the data naturally from the Department of Hadith Science, Ushuluddin Faculty of UIN Sunan Kalijaga Yogyakarta and the Faculty of Islamic Studies and Civilization, Qur'an and Sunnah, Kolej Universiti Islam Antarabangsa Selangor (KUIS) Malaysia. These data were obtained naturally without the researchers' intervention so the researchers could validate the data from both sources. Three data collection methods have been employed in this study: were interviews, observation, and documentation. The data analysis technique in this study followed Miles and Huberman's framework, consisting of data reduction, data presentation, and conclusion drawing.

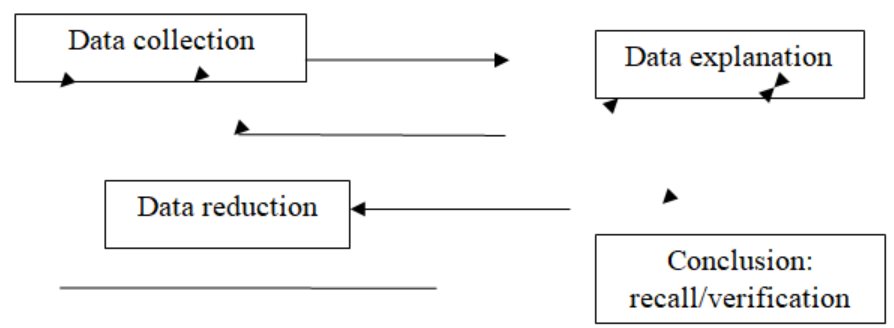

Fig.1. Process Data Analysis Offered by Miles and Huberman 


\section{Result and Discussion}

KUIS is an Islamic higher education managed by the Selangor Islamic Religion Council (MAIS) and is under the coordination of IPTS. The establishment of KUIS showed the commitment of the kingdom of Selangor in education and science. KUIS is aimed to produce da'i (Islamic preacher), ulama, and umara (leader).

KUIS's motto is "the catalyst of tradition of science". Its campus' is architecturally characterized by the historical glory of Islam in Andalusia. KUIS is an aggressive and proactive higher education institution. It provides academic programs based on monotheism and modernism principles to be a qualified Islamic university. This effort is supported by the lecturers and the staff (mudarris, mu'allim, muaddib, murabbi, and murshid).

KUIS offers educational programs for basic level, diploma, bachelor, master, and doctoral degrees of philosophy in accordance with the Malaysian Eligibility Agency (MQA) standards. KUIS has some competitive disciplines, including Islamic studies, commerce, Islamic banking, education, communication, and information technology.

KUIS consistently produces professional staff and Muslims who are able to lead the community and develop Islamic knowledge. In addition, KUIS also plays an important role in providing an alternative to continuing studies to a higher level. To establish its academic tradition, research and innovation, KUIS expands the network through some MoUs and MoAs with national and international institutions.

KUIS programs include holistic development programs, healthy environment, good climate (qudwah hasanah), academic brilliance, and Khidmat Ummah program. In addition, KUIS train graduates who have good morals, religiously and nationally devoted, which in the end can help to build a safe and prosperous country (baldatun thayyibatun wa rabbun ghafur) using its good facilities,.

KUIS curriculum includes a variety of religious subjects such as al hadith, ulumul hadith, legal traditions, rijal al-hadith, the science of takhrij hadith, and manahij muhaditsin. Rijal alhadith subject focuses on the normative aspects of the study of companions of prophet Muhammad SAW, particularly the 'adalah al-shahabah'. Some Islamic scholars suggested that the companions of Prophet Muhammad are considered as human beings who are free of criticism and free from practice of 'Ilmu al-Jarh wa al-Ta'dil'. Praises to companions is always based on texts, which are enforced as arguments that justify theologically. All companions are described as honest people without exception.

One example of the normative paradigms is based on Surah Ali 'Imran verse 110 which stated that all companions are fair:

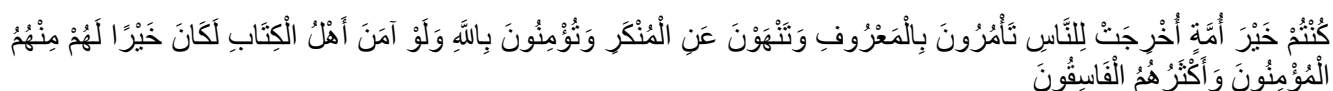

"Ye are the best community that hath been raised up for mankind. Ye enjoin right conduct and forbid indecency; and ye believe in Allah. And if the People of the Scripture had believed it had been better for them. Some of them are believers; but most of them are evil-livers."

Some hadith scholars concluded that the word خَيْرَ أَمَّة Prophet Muhamad SAW are the best people, just, and not allowed to be criticized. Some hadith experts and interpreters who have a broader view stated that the sentence خَيْرَ أُمَّةٍ that Muslims who do al-amr bi al-ma'ruf wa al-nahiy 'an al -munkar and believe in Allah are better than other people. The interpretation shows that not only the prophet Muhammad 
SAW's companions, but also other Muslims can achieve the goal stated in the ayah. Another popular hadith which support this pinion opinion is a hadith of 'adalah al-sahabah', as follow:

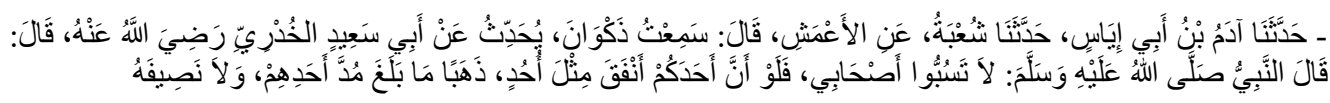

"Do not all of you abuse my companions, for the sake of the Essence whose soul is in its hands, if one of you gave alms of gold as big as the hill of Uhud, surely your alms would not equal one or half of my best friend."

This hadith appeared when the Prophet heard the debate between Khalid b. Walid and 'Abd al-Rahman b. 'Awf. The Prophet rebuked Khalid b. Walid with the Hadith. According to alBaidawiy, the use of these hadith was due to the virtue of companions and the small number of friends before Fath Makkah. After Fath Makkah, the situation changed because the number of companions increased (Shuhudi, 1995).

Based on the context above, Prophet Muhammad prohibited the act of swearing or swearing between one friend and another, as in the example of the debate between Khalid $b$. Walid and 'Abd al-Rahman b. 'Awf. Isma'il suggested that researching the companions' personality is not the same as insulting them. The research objective is to determine the authenticity of the hadith of the Prophet Muhammad as a source of Islamic teachings.

The study of hadith related to Shi'a is still based on normative theology and truth claims. The hadith studies assume that there is no truth and safety for humans except in religious thinking. For example, the hadith studies in KUIS focus on the judgment of heretical Shiites in understanding the hadiths of the Prophet Muhammad and question the credibility of the narrators of hadith and similar studies. Studies on the issue of liberalism and orientalism are focused on the issue of the narrators' misunderstanding of the hadith, the results of liberalist and orientalist studies, but it does not emphasize the way of thinking, methodology and approach.

UIN Sunan Kalijaga Yogyakarta is one of the leading Islamic religious colleges in Indonesia. It has a hadith science study program which vision is "excellent and leading in the integration and development of hadith and scientific studies for civilization" aims to produce scholars of hadith science who are professional and have academic qualifications. A scholar is able to carry out critical-analytical research to participate in solving social problems related to the discipline of hadith. To support these visions and objectives, the department of hadith studies offers curriculums which include hadith science, hadith software studies, hadith hermeneutics, hadith on aqidah and akhlak, legal and social hadith, ma'ani science, research methodology on hadith and living hadith.

UIN Sunan Kalijaga Yogyakarta follows the historical scientific paradigm. Learning hadith means studying and examining the history of the Prophet Muhammad. History is important occurrence and event that happened in the past (Poerwadaminta, 1991). This historical event is not only seen from the material of the events, but also seen from other aspects. Historical events must be viewed based on who the person was, where the event happened, when the events occurred, and why the events occurred. The historical approach in the study of hadith requires the readers and scholars of hadith to use critical reasoning in understanding the prophet's hadiths. A person who wants to understand the prophet's hadith needs the knowledge of asbabul wurud (knowledge of the history/background of hadith in a broad sense) by taking into account the historical-empirical conditions of the Hadith conveyed by the Prophet. 
Studies on the history of the Prophet Muhammad require rich data related to the Prophet's life fourteen centuries ago. One important course related to the history of the prophet is hermeneutics course. In this course, students studying the prophet's hadith were required to understand the situational and historical-sociological backgrounds of Arab society at the time the prophet Muhammad issued his hadith.

Reading the prophet's hadith means trying to give meaning and interpret hadith. Dilthey emphasized that interpreting (verstehen) is a process to understand the text as a part of historical expression, understanding what needs to be reproduced, and not the inner condition of the author, as well as understanding the meanings of historical events that drive the creation of the hadith (Masnur, 2005). Thus, when someone reads the prophet's, he/she should focus on the text and other aspects (Bertens, 1985).

Living sunnah course, which emerged to response the shift in perspective regarding the prophet's hadith, also represents the historicity paradigm. The course aims to standardize the meaning of the hadith and narrow the scope of meaning of the hadith down. The prophet Muhammad' traditions, which all contain Islamic teaching values, have continued to develop until now. With the sustainability of this tradition, Muslims today can enjoy, understand, record, and carry out the guidance of Islamic teachings in accordance with what the Prophet Muhammad had done and exemplified (Ali, 2015). In addition to the methodological approach, the reference books used in the Living Hadith subject also reflect a scientific paradigm with a historical approach, such as Richard C. Martin's "Islamic Studies Approach in Religious Studies", Sahiron Syamsudin's "Living Qur'an Methodology and Living Hadith", and M. Atha' Mudhhar's "Islamic Studies Approach" books.

The two subjects methodologically will influence lecturers and students in studying other courses. The thematic hadith studies and subjects (method of syarah hadith, ma'ani al-hadith science, aqidah-akhlak hadith, legal and social hadith, political and fconomic hadith, science of hadith , qiraatul kutub syarah hadith, thematic tafsir hadith and reading text on hadith) have a major influence on lecturers and students, .

The normative theological paradigm is in fact still used in several courses in the hadith science study program of UIN Sunan Kalijaga Yogyakarta, especially in mustalah hadith and observational studies of hadith courses. For example, students taking observational studies of Hadith course tend to use textual understanding of the hadith. Arabic language is a big obstacle for students of Hadith Science study program. Most students rely on Indonesian translation to read and understand the prophet's hadiths, so they may only understand hadiths textually. Hadiths were produced fourteen centuries ago, so the cultural context and the historical aspects that surround the production of hadiths should be taken into account. However, truth claims that are characteristic of the normative paradigm are starting to be abandoned. This is a good development in Islamic studies, especially the study of hadith. This shows that despite the tendency to use the historical paradigm with logical reasoning, it does not negate the normative paradigm in understanding some learning material in certain subjects.

\section{Integrative Paradigm}

Abdullah (2002) explained that the science integration-interconnection paradigm between various scientific fields and approaches used in conducting a study are related to one another. All scientific disciplines being studied are from the same source, but the dimensions and focus of attention in each discipline different (Abdullah, 2002). 
Following Abdullah's concept above, the hadith department at UIN Yogyakarta inclines to use the integration-interconnection paradigm, as demonstrated in Science Philosophy and Islamic Philosophy courses which aimed as the basis for scientific development in the hadith science. Methodologically, several courses were offered to build students' critical reasoning in understanding the prophet's hadith. This critical reasoning was aimed to dismantle the systematic Islamic knowledge. Science which should have been historical in nature has turned into a closed, intolerant, rigid nature, and shows more ideology than the religious spirit. Social theories in hadith studies, religious social research methodology, hadith hermeneutics, contemporary hadith thought, orientalist hadith thought, living hadith and hadith and media courses were offered to stimulate the development of the study of hadith at UIN Sunan Kalijaga. The historical aspects of the hadith can be well revealed, so that the understanding of the hadith of Prophet Muhammad is relevant with today's challenges.

\section{Conclusion}

The department of hadith studies at UIN Sunan Kalijaga Yogyakarta used the historical and integrative scholarly paradigm in the teaching process. However, the department's syllabus showed that introductory courses offered for freshman students who experienced transition from high school to college employed a normative scientific paradigm. On the other hand, the hadith department at KUIS Selangor Malaysia employed a normative scientific paradigm to develop the knowledge of hadith. Of the various subjects and syllabi studied, the lack of methodological subjects offered by the study program is an indicator that studies with a normative approach are still dominated with the Qur'an and Sunnah studies.

\section{References}

[1] Ramli, Abdul Wahid. (2006). "Perkembangan Kajian Hadis Di Indonesia: Studi Tokoh Dan Organisasi Masyarakat Islam”, Jurnal Al-Bayan Vol. 4 tahun.

[2] Isma'il, M. Shuhudi. (1995), Kaedah Kesahihan Sanad Hadis, Telaah Kritis dan Tinjauan dengan Pendekatan Ilmu Sejarah. Cet. II, Jakarta, PT. Bulan Bintang.

[3] Bertens, K. (1985), Filsafat Barat Abad XX, Jakarta: Gramedia.

[4] Abdullah, M. Amin. (2002). "Kata Pengantar" dalam, Pendekatan Terhadap Islam dalam Studi Agama, terj. Zakiyuddin Bhaydawi, Surakarta: Muhammadiyah University Press.

[5] Masnur, Hery dan Damanhuri, Muhammad. (2005), Teori Baru Mengenal Interpretasi, Yogyakarta: Pustaka Pelajar.

[6] Ali, Muhamad. (2015), “Kajian Naskah dan Kajian Living Qur'an dan Living Hadith”, Journal of Qur'an and Hadith Studies, Vol. 4, No. 2.

[7] Tasrif, Muh. (2007). Kajian Hadis di Indonesia, Ponorogo: STAIN Ponorogo Press.

[8] Hayati, Naila. (2015). "Pemilihan Metode Yang Tepat Dalam Penelitian (Metode Kuantitatif Dan Metode Kualitatif)", Jurnal Tarbiyah al-Awlad, Vol 4, No 1 tahun.

[9] Poerwadaminta, W.J.S. (1991), Kamus Umum Bahasa Indonesia, Jakarta: Balai Pustaka. 